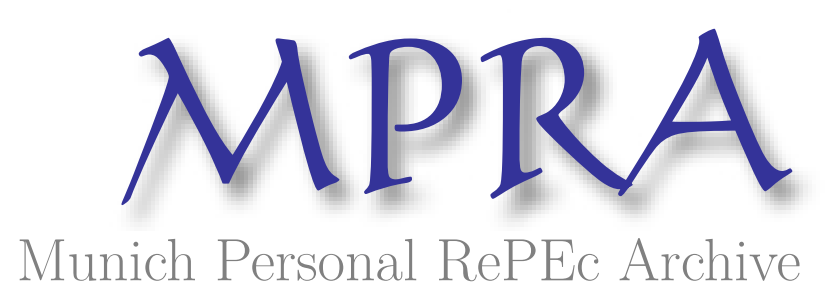

\title{
Fund Manager Characteristics and Performance
}

Fang, Yi and Wang, Haiping

8 September 2014

Online at https://mpra.ub.uni-muenchen.de/60012/

MPRA Paper No. 60012, posted 18 Nov 2014 11:09 UTC 
Fund Manager Characteristics and Performance

Yi Fang ${ }^{1}$ and Haiping Wang ${ }^{2}$

September 8, 2014

1. Corresponding author: Yi Fang is an associate professor at the Center for Quantitative Economics, Jilin University, Changchun, China, and the Business School, Jilin University, Changchun, China. Correspondence to Business School, Jilin University, 2699 Qianjin Street, Changchun,130012, China; email danielfang@163.com; tel. +86 133-5431-8008; fax +86 (431) 8516-6347.

2. Haiping Wang is an assistant professor at the School of Administrative Studies, York University, Canada. Correspondence to 258 Atkinson Building, 4700 Keele Street, Toronto, ON, M3J 1P3, Canada; email hpwang@yorku.ca; tel. +1 (416) 736-2100 ext. 20873; fax +1 (416) 736-5963.

\section{Acknowledgments}

The authors gratefully acknowledge the financial support of the National Natural Science Foundation of China (Grants No. 71371084 and No. 71001044) and the Liberal Arts and Professional Studies International Collaboration Grant at York University. 


\section{Fund Manager Characteristics and Performance}

Abstract: This study establishes a multi-tier framework to evaluate how fund manager characteristics systematically affect mutual fund performance. The framework includes three tiers of performance elements: 1) comprehensive performance, 2) return and risk, and 3) timing skill and picking ability. Using performance decomposition, our evidence indicates that various characteristics take distinct channels to influence return, risk, and fund manager abilities, which in turn affect comprehensive performance. In particular, having a degree of Master of Business Administration or a Chartered Financial Analyst qualification is significantly associated with a fund manager's better stock picking ability, higher excess returns, and better comprehensive performance.

Keywords: Fund manager characteristics; mutual fund performance; Sharpe ratio; excess return; total risk; market timing skill; stock picking ability 


\section{Fund Manager Characteristics and Performance}

\section{INTRODUCTION}

Research has shown that fund performance is related to a number of fund manager characteristics. However, the mechanism by which these characteristics affect fund performance is still a black box.

This study establishes a three-tier framework to fill the above gap. Considering two fundamental aspects of fund performance, that is, return and risk, we adopt the Sharpe ratio (Sharpe, 1966) as a measure of comprehensive performance. Our paper takes three steps to reveal the channels through which fund manager characteristics influence fund performance. First, we study the direct association between various manager characteristics and comprehensive performance to provide a general idea of the relationships. Second, we decompose the comprehensive performance measure into excess return and total risk and study the impact of manager characteristics on these two dimensions. The decomposition allows us to throw light on the mechanism by which characteristics act on comprehensive performance. In other words, some characteristics are relevant to risk-related performance, while others have an impact on return-side performance. Third, we decompose excess return into market timing skill and stock picking ability. We argue that certain characteristics of fund managers are predictive of their ability to pick stocks or to time transactions, which in turn lead to different return levels and thus various comprehensive performances.

Under the above framework, we investigate Chinese open-end stock funds to fill the void in the literature about the association between fund manager characteristics and fund performance in emerging capital markets. China is the most important emerging country and the world's second largest economy. The Chinese capital market has developed along a different path from that of most developed countries. ${ }^{1}$ However, empirical evidence regarding fund performance in developed countries is often not generalizable to the Chinese market setting. In addition, anecdotal evidence shows that many successful fund managers in developed countries might not do well in China. ${ }^{2}$ Hence, examination of the determinants of fund performance in the Chinese setting is of particular interest. 
In this paper, we focus on 11 fund manager characteristics, which are classified into four categories: physical characteristics, educational background, work experience and professional qualifications. The choice of the characteristics variables is based on the unique features of fund managers in China and is subject to the limitations of the database.

Our panel and cross-sectional data analyses provide consistent evidence that having a degree of Master of business administration (MBA) or a Chartered Financial Analyst (CFA) qualification is significantly associated with a fund manager's better stock picking ability, higher excess return, and better comprehensive performance. Further decomposition results indicate that excess return is the main driver of comprehensive performance; excess return can be well explained by the manager's stock picking ability and market timing skill. In addition, stock picking ability has a dominant influence on excess return. Therefore, the impact of having an MBA degree or a CFA qualification on fund performance is through the action of these characteristics on stock picking ability, which in turn affects excess returns and thus, comprehensive performance. We also find that gender and university major act on fund risk.

This study contributes to the literature in several ways. First, it introduces a framework to identify the mechanism through which fund manager characteristics affect fund performance. Second, our findings in the Chinese stock market complement the established empirical evidence on the US market. Given that China is now the world's largest emerging economy, our results are of great importance to not only Chinese investors, but also international investors interested in the Chinese capital market. Third, our study is the first to empirically test the decomposition of excess return into fund managers' stock picking ability and market timing skill.

\section{CONCEPTUAL FRAMEWORK}

While previous studies have shown evidence that fund performance is associated with several manager characteristics, a majority of them ignore potential linkages between manager characteristics 
and factors that contribute to comprehensive performance. We develop a three-tier conceptual framework to uncover the relationships: a) the determinants of comprehensive performance, b) decomposition of comprehensive performance into excess return and risk, and c) further decomposition of excess return into market timing skill and stock picking ability. Our conceptual framework is outlined in Figure 1.

\section{INSERT FIGURE 1 ABOUT HERE}

The framework starts with the determinants of comprehensive performance. We believe that a good comprehensive performance measure should encompass both return and risk to capture the benefits and costs of a portfolio investment. For this purpose, three well-recognized measures stand out as available candidates, namely the Sharpe ratio, the Treynor index (Treynor, 1965) and Jensen's alpha (Jensen, 1972). The Treynor index is defined as a portfolio's abnormal return divided by systematic risk. The problem with this index is that it fails to account for idiosyncratic risk. Fund manager characteristics are believed to be systematically related to their ability to diversify idiosyncratic risk, resulting in better fund performance. Jensen's alpha, measured as the risk-adjusted return, or "pure return," nets the premium-based systematic risk and does not reflect the return per unit of risk, making it impossible to conduct a cross-sectional comparison of managers' performance. Additionally, Roll (1978) points out that Jensen's alpha is sensitive to the choice of market index and may not be a proper measure of the quality of portfolio managers. The Sharpe ratio, defined as the excess return scaled by total risk, is regarded as a superior measure of comprehensive performance. First, the ratio is seen as the most extensively applied as well as the most influential empirical performance measure (Eling, 2008; Lo, 2002). It evaluates the excess return gained per unit of total risk and provides a convenient summary of the risk and return of investment strategies, thus outperforming single-factor measures. Moreover, the ratio is consistent with the theory of expected utility maximization under the assumption of elliptically distributed returns (Ingersoll, 1987), indicating great external validity. In addition, Dowd (1999) argues that the ratio is an appropriate measure of performance when a fund represents either an entire risky investment or only a portion of investors' risky investments. 
The second tier in our framework is a decomposition of comprehensive performance into excess return and total risk, two dominant aspects of performance. We conjecture that fund manager characteristics affect comprehensive performance through their impact on return, risk, or both. A mapping between manager characteristics and the two dimensions of performance helps further unravel the characteristics-performance black box. This could serve as useful information for investors to meet their specific risk preferences and return expectations.

The third tier of our framework involves a further decomposition of return. Both financial institutions and investors might care about the sources of return that could ultimately bring in monetary benefits. Such information may help financial institutions recruit abled fund managers to obtain high revenue and assist investors in selecting the right fund manager to achieve capital gains. Following Treynor and Mazuy (1966), we decompose return into managers' stock picking ability and market timing skill, using the following equation:

$$
R_{p, t}-R_{f, t}=\alpha+\beta_{1}\left(R_{m, t}-R_{f, t}\right)+\beta_{2}\left(R_{m, t}-R_{f, t}\right)^{2}+\varepsilon_{p, t}
$$

where $R_{p, t}$ represents the return of portfolio $p$ in period $t, R_{f, t}$ denotes the risk-free interest rate in period $t, R_{m, t}$ denotes the return of the market portfolio in period $t, \alpha$ measures stock picking ability, and $\beta_{2}$ measures market timing skill. A positive $\alpha$ and a positive $\beta_{2}$ indicate that the fund manager has good picking ability and timing skill, respectively. Therefore, the decomposition of return can provide insight into the specific reasons why certain fund managers outperform others. Such decomposition allows for further mapping between fund manager characteristics and the specific source of return that influences comprehensive performance.

\section{VARIABLE SELECTION}

\subsection{Dependent Variables}

The dependent variables in our three-tier empirical analysis are a) the Sharpe ratio, b) excess return and total risk, and c) stock picking ability and market timing skill. Specifically, excess return is 
measured as the difference between portfolio return and risk-free return, total risk is proxied as the standard deviation of excess return, and the Sharpe ratio is measured as the excess return divided by total risk. Stock picking ability and market timing skill are reflected by the coefficients $\alpha$ and $\beta_{2}$ in Equation (1).

\subsection{Independent Variables}

\section{1) Physical characteristic}

Atkinson, Baird and Frye (2003) find that gender influences the decision making of the mutual fund investor. Singh (2012) shows that males are more overconfident than females. Moreover, $\mathrm{Hu}, \mathrm{Yu}$ and Wang (2012) demonstrate that female fund managers outperform male managers in cost control and risk management. Thus, our regression models include GENDER, a dummy variable that takes the value one if a fund manager is female and zero otherwise.

Golec (1996) argues that age can gauge both the experience and stamina of fund managers in their demanding job, which result in better and worse performance, respectively. In our regression models, AGE represents a discrete variable that measures a manager's age rounded to the year.

\section{2) Educational background}

A fund manager's education suggests the manager's overall professional capability. Chevalier and Ellison (1999) suggest that a higher degree of education indicates greater intelligence and a better knowledge base. They also consider that educational experience in top universities helps fund managers build up a social network that boosts their informational advantage. Since a majority of fund managers in our sample have a bachelor's degree, our analysis concentrates on the influences of having a master's degree or a PhD on performance measures. We also introduce a special master's degree, the MBA, in our analysis. Golec (1996) finds that managers with MBAs outperform those 
without them. An MBA degree is well-recognized in China. Upon completion of an MBA program, the student is expected to master various business concepts and strategies and apply them in daily business operations.

A fund manager's academic specialization, that is, whether the manager majored in economics or a business academic program, is likely to affect the manager's fund management skills. This is because specialized training equips a fund manager with specific knowledge and familiarizes him/her with useful tools to manage fund. Economics student and non-economics students make investment decisions differently (Carter and Irons, 1991). In addition, Zhou (2010) illustrates that risk preferences are influenced by academic specialization.

Lee, Yen and Chen (2008) demonstrate that managers with overseas experience usually have better foreign language skills, which broaden horizons and provide more accessible information channels via an established global network, thus leading to better fund performance.

Therefore, we create the dummy variables MASTER, PHD, MBA, MAJOR, and OVERS. Specifically, MASTER, $P H D$, and MBA are equal to one if a fund manager's highest degree is a master's or a PhD or the manager received an MBA degree, respectively, and zero otherwise. In particular, if a fund manager has an MBA degree, the value of MASTER is zero and that of MBA is one and vice versa; MAJOR equals one if a manager's academic specialization is in a non-business or non-economics field and zero otherwise; and OVERS takes the value one if a manager has overseas study experience and zero otherwise.

\section{3) Work experience}

Lee, Yen and Chen (2008) provide evidence that manager experience has an effect on fund performance. Therefore, our investigation includes a variable EXP representing the number of years of working in an investment-related industry. Furthermore, manager turnover is a documented factor that affects performance (McEvoy and Cascio, 1987). The impact of turnover on performance can be 
twofold: First, high turnover may indicate a lack of loyalty to the company, thus leading to worse performance; second, high turnover can also be a sign of intensive competition, which is likely to translate into better performance. Therefore, we do not predict the sign of the association between manager turnover and performance. The variable TURNO denotes the number of companies a manager has worked in since the manager's first day in the industry.

\section{4) Professional qualification}

A number of studies show that CFA designations are significantly associated with better performance in the US setting (e.g., Gottesman and Morey, 2006; Shukla and Singh, 1994). The CFA charter is a globally recognized credential. Earning the CFA demonstrates expertise with a broad range of knowledge and skills needed for a competitive career in investment. The CFA qualification system was introduced in China only about 10 years ago, and more time might be needed to reveal its practical benefits. So, we test the relationship between having a CFA designation and fund performance: CFA is a dummy variable that equals one if a manager possesses a CFA designation and zero otherwise.

The Certified Public Accountant (CPA) qualification focuses on accounting, auditing, cost management, strategies and risk management, and economic and tax laws. It has been around in China for over 30 years and is a widely accepted credential. Therefore, we also include in the analysis $C P A$, a dummy variable that takes the value one if a fund manager possesses a CPA credential and zero otherwise.

\section{DATA AND METHODOLOGY}

We analyze open-end stock funds. The data of fund manager characteristics are retrieved from the Wind database. When the AGE variable is missing, following Chevalier and Ellison (1999), we assume that each manager obtained a bachelor's degree at the age of 23 and then estimate the age of managers by adding 23 years to the number of years at work. To construct the OVERS variable, we 
exclude observations for which the locations of a manager's previous foreign employer are not available and when a manager underwent only a short period of training overseas.

The performance data are obtained from the Wind database as well. The China A Index is adopted as a proxy for the market portfolio, which is weighted by circulation equities and constructed by sampling all stocks traded in the Shanghai and Shenzhen A-share markets. The risk-free rate is defined as China's one-year deposit rate, because the majority of bonds issued by the Ministry of Finance of China are for longer than three-year period, and the supply of short-term bonds is very small. Monthly fund portfolio return is directly available in the database. The Sharpe ratio, excess return, total risk, picking ability, and timing skill are estimated by the monthly market return, fund portfolio return and risk-free rate.

The sample period covers from January 2008 (few observations are available before 2008 in the Wind database) to June 2011. In total, there are 287 funds. The average turnover frequency for fund managers is 18 months. Therefore, we consider fund performance in an interval of 18 months. We assume that it takes a fund manager six months to set up a portfolio, and thus we examine performance in the next 12 months following the initial setup. The whole sample period is divided into three sub-periods, each spanning 18 months-January 2008 to June 2009, January 2009 to June 2010, and January 2010 to June 2011 -in which the first six months of every sample is assumed to be the portfolio set-up period. Our research evaluates the performance of funds in the last 12 months in each sample. Following the criteria, we end up with 157 fund managers.

We employ an unbalanced panel data model (Davis, 2002) with time fixed effects for our empirical analysis because the fund data have an unbalanced panel structure. For example, if a fund manager was only appointed during 2007-2009, this manager should be included in our sample based on our selection criteria. However, the performances of the manager are null during 2009-2011. We apply White cross-sectional standard errors to eliminate the effect of heteroscedasticity due to the existence of individual differences among fund managers. Additionally, our model includes a test of fixed effect 
with regard to the influence of stock market's ups and downs on the annual horizon. The likelihood ratio of the following model is adopted to test the time fixed effect term:

$$
y_{i, t}=\alpha+\sum_{k=1}^{11} \gamma_{k} x_{i, t}^{k}+\delta_{t}+\varepsilon_{i, t}
$$

where $y_{i, t}$ is a performance index involving the Sharpe ratio, excess return, total risk, stock picking ability, and market timing skill; $x^{k}$ represents variables corresponding to 11 manager characteristics; and $\delta_{t}$ denotes the time fixed effect.

To illustrate the validity of the panel data model, we also adopt the cross-sectional model to analyze the relationships among manager characteristics and fund performances. The cross-sectional model is developed by adding year dummies as additional explanatory variables and deleting observations with missing data. Our cross-sectional model employs the White covariance matrix again to avoid the issue of heteroscedasticity.

Table 1 presents the descriptive statistics of the variables.

\section{INSERT TABLE 1 ABOUT HERE}

The Sharpe ratio ranges from -0.225 to 0.443 , demonstrating sufficient differences in comprehensive performance between the best and worst managers. The minimum and maximum returns are -1.999 and 2.816, which indicate significant performance gaps among the managers. Similar evidence can be discovered in risk, market timing skill, and stock picking ability.

The variables depicting physical characteristics are gender and age. Among the 157 fund managers, 12 are females. The average age of the fund managers is 36.581 years. The minimum and maximum ages are 30 years and 48 years, respectively. Li, Zhang and Zhao (2011) report that the average age of the U.S. hedge fund managers is 45.43 years, and Chevalier and Ellison (1999) show an average age of 44.18 years for the U.S. fund managers. Compared with U.S. fund managers, Chinese fund managers are, on average, eight to nine years younger. 
The educational variables considered are the possession of a master's, a PhD degree, and an MBA and one's major. In our sample, $70.5 \%$ of the funds are administered by managers whose highest education is a master's degree, but only $11.4 \%$ of funds are managed by a PhD holder. A total of $12.3 \%$ of the funds are held by managers with an MBA, a much lower percentage than the reported figure of $58.1 \%$ for U.S. fund managers in Gottesman and Morey's (2006). Furthermore, $73.7 \%$ of the funds are administered by managers with either a business or an economics degree.

In terms of experience, the average time spent in the industry is 10.5 years, with a minimum and a maximum of 4 years and 19 years, respectively. According to Li, Zhang and Zhao (2011), the average industry experience of U.S. hedge fund managers is 19.45 years, much longer than the average industry experience of managers in our sample, although the manager types are not comparable. The average number of firms a manager worked in is 1.244 , with the highest turnover being four firms since the manager's initial appointment. Only 13 fund managers had overseas study experience.

In our sample, only 25 fund managers, or $15.9 \%$ of the total, have CFA or CPA qualifications. Specifically, the percentage of funds held by managers with a CFA is $9.4 \%$, far less than the $50.20 \%$ in a sample of U.S. fund managers (Gottesman and Morey, 2006).

All in all, compared with US managers, the Chinese managers are younger but have less industry experience and fewer have an MBA or a CFA. We also estimate the correlation matrix of the characteristics variables. The correlation coefficients are relatively low. Therefore, our regressions do not suffer from a severe multicollinearity problem.

\section{EMPIRICAL RESULTS}

5.1 Manager Characteristics and Fund Performance 
Table 2 includes the results based on our panel data model. We run five regressions using the Sharpe ratio, return, risk, stock picking ability, and market timing skill variables as proxies for performance, respectively. All regression models have time fixed effects because the $F$-values are all greater than the critical values, with a significance level of $5 \%$.

\section{INSERT TABLE 2 ABOUT HERE}

1) Comprehensive performance regression

The second column of Table 2 shows the associations between fund manager characteristics and comprehensive performance. The results suggest that fund comprehensive performance is significantly related to $A G E, M B A, O V E R S$ and $C F A$.

The variable $A G E$ is negatively correlated with the Sharpe ratio. It seems that younger managers achieve higher returns for each unit of risk. Our results are consistent with Shukla and Singh (1994) and Chevalier and Ellison (1999). One reason might be that younger managers are better motivated to work hard since they have a longer way to go in their entire career. Another reason could be that younger managers are physically more capable of taking on investment positions, which are time and effort intensive.

The coefficient of OVERS is negative, indicating that managers with overseas experience do not outperform managers educated in China in terms of excess returns per unit of risk. One possible explanation is that China's financial system, capital market supervision, and legislation are quite different from those in developed countries. Knowledge and skill obtained from overseas cannot be directly applied in China, resulting in suboptimal investment decisions and trading strategies. On the other hand, fund managers educated exclusively in China are more familiar with the institutional features of the Chinese capital market, and as a result, obtain better performance. 
Possession of an MBA is significantly positively associated with the Sharpe ratio. The evidence indicates that specialized business education results in better performance, which is consistent with the findings in mature capital markets (e.g., Golec, 1996).

Similar to the results of Shukla and Singh (1994) in a developed country setting, we find that managers with CFA qualifications have better performance. This result demonstrates that the CFA charter is an influential qualification in the investment field. Since obtaining the certificate requires a good knowledge of investment, as well as an understanding of ethics, laws, accounting, data analysis, and portfolio management, such a qualification leads to better fund manager performance.

\section{2) Excess return and total risk regressions}

The third and fourth columns of Table 2 provide the results for the return and risk equations. The variables AGE, MASTER, MBA, and CFA significantly affect excess returns, while GENDER and MAJOR significantly influence risk.

It is in line with $\mathrm{Li}$, Zhang and Zhao (2011) that the coefficient of $A G E$ in the return model is negative. However, the coefficient of $A G E$ is not significant in the risk model. The results indicate that younger fund managers are generally better at managing funds for higher returns without compromising the riskiness of the fund. The findings suggest that the higher performance achieved by younger managers is primarily driven by higher returns rather than lower risk.

The variable MASTER and return is positive correlated at the $10 \%$ significance level. However, MASTER does not contribute to the risk of fund portfolios. Similar results apply to CFA: having a CFA is associated with higher excess returns at the $5 \%$ significance level, which is consistent with Friis and Smit (2004), but it is not significantly associated with a lower risk. The aggregate effects of MASTER and CFA differ in that MASTER is not significantly associated with the Sharpe ratio but CFA is. This difference might explain their different impacts on aggregate fund performance, that is, the Sharpe ratio. 
According to the results of the risk regression, GENDER and MAJOR significantly affect total risk. The negative coefficient of GENDER implies that Chinese female fund managers are more likely to choose a less risky portfolio than their male counterparts, which is consistent with the theories of risk taking proposed by Zuckerman (1991). ${ }^{3}$ The result is not unexpected, since it is well known that males are more confident in choosing portfolios (e.g., Barber and Odean, 2001). In addition, our finding about the variable MAJOR supports Zhou (2010) that a fund manager who is a non-business or non-economics major incline to take fewer risks.

Interestingly, neither GENDER nor MAJOR has a significant influence on excess return or the Sharpe ratio. These two characteristics seem to be pure risk factors rather than return or comprehensive performance factors.

\section{3) Ability regressions}

The fifth and sixth columns of Table 2 contain the results of the market timing skill and stock picking ability regressions. It is surprising that only the variable MASTER is significantly associated with timing skill. The significantly negative coefficient indicates that a fund manager who obtains a non-MBA master's degree underperforms his/her MBA peers in timing fund transactions. On the contrary, picking ability is positively correlated with three educational variables—MASTER, PHD and MBA—and two professional qualification variables-CPA and CFA. Our results suggest that having an MBA, a non-MBA master's degree, or a PhD leads to better stock picking ability; having a CPA or CFA also improves a manager's portfolio construction skills. It seems that a higher level of education and the possession of professional qualifications equip a fund manager with useful investment knowledge to better manage portfolios.

Table 3 provides the regression results based on the cross-sectional model. In the comprehensive performance regression, the coefficient of AGE is significantly negative, and those of MASTER, MBA, and CFA are significantly positive. In the return regression, the coefficients of $A G E, M B A$, and CFA 
are significant. Consistent with the panel data results, GENDER and MAJOR are significantly associated with risk. In the timing skill regression, only $P H D$ is significant. In the picking ability regression, MASTER, PHD, MBA, and CFA are significant.

Overall, the results of the cross-sectional models are generally in accordance with those of the panel data models. From the two types of models, we find that 1) having an MBA or a CFA is significantly positively associated with comprehensive performance, excess return, and stock picking ability, 2) the correlation between lower risk and being a female manager or having a non-business or noneconomic major is significant, and 3) better stock picking ability is significantly related to having a general master's degree, MBA, PhD, or CFA.

\section{INSERT TABLE 3 ABOUT HERE}

\subsection{Performance Decompositions}

The above findings indicate that no common set of fund manager characteristics affects all components of performance, that is, excess return, total risk, timing skill, and picking ability. In particular, the characteristics that affect excess return and those that impact total risk are mutually exclusive. Since excess return and total risk are the two fundamental components of comprehensive performance, it is of great interest to compare their sensitivity with respect to comprehensive performance to determine which set of manager characteristics deserves more attention when aiming for better comprehensive performance.

Our evidence shows that the manager characteristics that affect excess return and those that influence the Sharpe ratio are quite consistent, while the characteristic factors associated with total risk are completely different. Hence, we conjecture that, compared with total risk, excess return is the main driver of the Sharpe ratio. 
To verify this conjecture, we transform the equation for the definition of the Sharpe ratio by taking the logarithm of each element and then converting it to a change model. The change model addresses the concern that the Sharpe ratio and total risk may be non-stationary series. The model that decomposes the Sharpe ratio into excess return and total risk is as follows:

$$
\Delta \operatorname{Ln}\left(S_{p, t}\right)=\alpha+\beta_{1} \Delta \operatorname{Ln}\left(R_{p, t}\right)+\beta_{2} \Delta \operatorname{Ln}\left(\sigma_{p, t}\right)+\varepsilon_{p, t}
$$

where $S_{p, t}$ is the Sharpe ratio, $R_{p, t}$ is excess returns, and $\sigma_{p, t}$ is total risk. The coefficients $\beta_{1}$ and $\beta_{2}$ represent the elasticities of the excess return and total risk with respect to the Sharpe ratio respectively.

The Table 4 presents the regression results. The adjusted $R^{2}$ value of the regression is 0.909 , implying that the Sharpe ratio is well explained by excess returns and total risk. The elasticity of excess return is 1.543 , a coefficient significant at least at the $5 \%$ level. The finding implies that a $1 \%$ increase in excess return will cause a $1.543 \%$ increase in the Sharpe ratio. However, the elasticity of total risk is not significant. Therefore, the change in the Sharpe ratio is primarily driven by the change in excess return, rather than that of total risk. As a robustness check, we use the Wald test to examine the null hypothesis $\beta_{2}+\beta_{3}=0$ to see whether the impacts of excess return and total risk on comprehensive performance are equal. The bottom row of Table 4 shows that the $\chi^{2}$ value of the Wald test is 32.287 and thus the null is rejected. Hence, our results provide convincing evidence that the Sharpe ratio is more sensitive to excess return than to total risk. This evidence explains well the findings in Tables 2 and 3 that fund manager characteristics that influence excess return also have an impact on comprehensive performance, while those associated with total risk have little to do with comprehensive performance.

\section{INSERT TABLE 4 ABOUT HERE}

The above results demonstrate that, excess return rather than total risk plays a dominating role in affecting comprehensive performance. It is critical to pay close attention to excess return and explore the components of return that explain why some fund managers outperform others in achieving higher returns. Following Treynor and Mazuy (1966), we further decompose excess return into timing skill 
and stock picking ability and use the following modified logarithmic difference model to test the sensitivities of market timing skill and picking ability with respect to excess return:

$$
\Delta \operatorname{Ln}\left(R_{p, t}\right)=\alpha+\beta_{1} \Delta \operatorname{Ln}\left(\text { Timing }_{p, t}\right)+\beta_{2} \Delta \operatorname{Ln}\left(\text { Picking }_{p, t}\right)+\varepsilon_{p, t}
$$

${\text { where } \text { Timing }_{p, t} \text { represents market timing skill and Picking }}_{p, t}$ represents stock picking ability.

Table 5 reports the results. The adjusted $R^{2}$ value is 0.859 , indicating that excess return can be well captured by the timing skill and picking ability of fund managers. The coefficients of timing skill and picking ability are both significantly positive, which suggests that both timing skill and picking ability can improve excess return. In comparison, the coefficient of picking ability is 0.206 , much greater in magnitude than that of timing skill $(0.110)$. Moreover, the standard deviation of picking ability $(0.0169)$ is much less than that of timing skill $(0.0245)$. We investigate whether the difference in the coefficients of timing skill and picking skill is statistically different from zero by adopting the Wald test. The null hypothesis is $\beta_{2}-\beta_{3}=0$. The $\chi^{2}$ value is significantly positive, which rejects the null hypothesis and indicates that picking ability has a greater influence on excess return than timing skill does. This evidence is well supported by the panel and cross-sectional data results in Tables 2 and 3 , in that return and picking ability are both related to $M B A$ and $C F A$, while timing skill is correlated with MASTER only.

\section{INSERT TABLE 5 ABOUT HERE}

In sum, the above decomposition results throw light on the mechanisms of how certain manager characteristics affect different elements of fund performance, which in turn influence the ultimate comprehensive performance.

When we decompose the Sharpe ratio into return and risk, the findings indicate that changes in the Sharpe ratio are almost completely driven by changes in returns. Risk, however, cannot significantly explain the Sharpe ratio. A manager who is younger and has an MBA or a CFA is significantly associated with both higher excess return and better comprehensive performance. At the same time, lower risk can be attributed to the presence of a female manager or a manager with a major in non- 
business or non-economics, which is correlated with better comprehensive performance. Therefore, fund manager characteristics affect comprehensive performance through their impact on excess return, but manager characteristics that influence risks do not help achieve better comprehensive performance.

We find that timing skill and picking ability are significant factors that affect excess return, which is the fundamental determinant of comprehensive performance. In addition, picking ability weighs more than timing skill in affecting excess return. Therefore, fund manager characteristics influence comprehensive performance mainly through their impact on picking ability, which in turn affects excess return and, ultimately, comprehensive performance.

In a word, we can draw a conclusion that fund managers who have an MBA or a CFA may be good candidates for investors because these qualities are associated with better stock picking ability, which results in higher returns and better comprehensive performance.

\section{CONCLUSION}

This study proposes a comprehensive framework to investigate the mechanisms of how fund manager characteristics affect fund performance. This framework consists of three tiers of performance elements: 1) comprehensive performance, 2) return and risk, 3) and timing skill and picking ability. By performance decomposition, the three-tier framework enables us to further explore the innate mechanism of how each manager characteristic acts on a certain element of performance, thus ultimately leading to different comprehensive performance.

Using both panel and cross-sectional data, we identify the fund manager characteristics that are correlated with various performance elements in the Chinese capital market. However, there is no common set of fund manager characteristics that affect all components of performance. Performance decomposition based on our framework shows that comprehensive performance is mainly driven by excess return rather than total risk. An explanation of the finding is that higher risk is well 
compensated by the accompanying higher returns and thus risk is not involved in the determination of comprehensive performance. An implication of the finding is that the manager characteristics that are associated with lower risk should not be taken into consideration in the selection of fund managers when the target is to achieve better comprehensive performance. Additionally, timing skill and picking ability affect a fund's excess return and the impact of picking ability is greater than that of timing skill. Therefore, we conclude that fund manager characteristics affect comprehensive performance mainly through their impact on managers' picking ability, which in turn affect excess return and, ultimately, comprehensive performance. The common characteristics that influence picking ability, excess return, and comprehensive performance are possession of an MBA or a CFA. We also address endogeneity concerns and rule out the possibility that managers with an MBA or a CFA share common characteristics, such as belonging to the same fund management firm or graduating from the same university. Therefore, having an MBA or a CFA is the most important quality of fund managers in China to outperform his/her peers in achieving better stock picking ability, higher excess returns, and better comprehensive performance.

Our results shed light on the effectiveness of an MBA and a CFA as educational and professional training tools in improving managers' abilities to manage mutual funds. An MBA not only supplies investment knowledge in a master's program, but also establishes a network from which fund managers can benefit when seeking inside investment information and hands-on experience. Meanwhile, a CFA provides fund managers sufficient training to better understand economic trends and make good investment decisions. Hence, our evidence gives investors an insight into how to select the right fund managers to administer their wealth. Our findings also provide implications for policy makers. While having an MBA or a CFA is the most important characteristic affecting a fund manager's performance, only $9.4 \%$ and $12.3 \%$ of fund managers have an MBA or a CFA, respectively. A greater supply of MBAs and CFAs will benefit the fund market's performance, which deserves the attention of policy makers in advocating and providing resources for MBA education and CFA training. 
Our findings demonstrate that gender and major are essential characteristics for considering risk preferences. For example, risk seekers are more likely to benefit from male managers with a business background, but risk evaders are better off with female managers without a business background. 


\section{Endnotes}

${ }^{1}$ The advent and evolution of the stock markets of developed countries are mainly induced by market forces. However, the creation of the Chinese stock market is highly regulated by central and local authorities. Chinese authorities have continuous effects on the development of the Chinese stock market.

${ }^{2}$ For example, Anthony Bolton, one of the United Kingdom's best-known investment fund managers and most successful investors, achieved a record $20 \%$ return compounded annually in the European and North American markets but lost 15\% in 2010 and 30\% in the first three quarters of 2011 in the Chinese market.

${ }^{3}$ In particular, this theory argues that men are inclined to take more risks because it is a socially instilled belief that risk taking is a highly valued masculine tendency. 


\section{REFERENCES}

Atkinson SM, Baird SB, Frye, MB. 2003. Do female mutual fund managers manage differently? Journal of Financial Research, 26(1): 1-18.

Barber BM and Odean T. 2001. Boys will be boys: Gender, overconfidence, and common stock investment. Quarterly Journal of Economics, 116 (1): 261-292.

Carter JR, and Irons MD. 1991. Are economists different, and if so, why? Journal of Economic Perspectives, 5(2):171-177.

Chevalier J, and Ellison G. 1999. Are some mutual fund managers better than others? Cross-sectional patterns in behavior and performance. Journal of Finance, 54(4): 133-148.

Davis P. 2002. Estimating multi-way error components models with unbalanced panel data structure. Journal of Econometrics, 106 (1): 67-95.

Dowd K. 1999. Financial risk management. Financial Analysts Journal, 55(4): 65-71.

Eling M. 2008. Does the measure matter in the mutual fund industry? Financial Analysts Journal, 64(3):1-13.

Friis, LB and Smit, EM. 2004. Are some fund managers better than others? Manager characteristics and fund performance. South African Journal of Business Management, 35(3): 31-40.

Golec JH. 1996. The effect of mutual fund managers' characteristics on their portfolio performance risk and fees. Financial Service Review, 5(2): 133-148.

Gottesman AA and Morey MR. 2006. Manager education and mutual fund performance. Journal of Empirical Finance, 13(2): 145-182.

$\mathrm{Hu} \mathrm{J}, \mathrm{Yu} \mathrm{H}$ and Wang Y. 2012. Manager attributes and fund performance: Evidence from Taiwan. Journal of Applied Finance \& Banking, 2(4): 85-101.

Ingersoll JE. 1987. Theory of financial decision making. Totowa, NJ: Rowman \& Littlefield.

Jensen MC. 1972. Capital markets: Theory and evidence. Bell Journal of Economics and Management Science, 3(2): 357-398.

Lee J, Yen P and Chen Y. 2008. Longer tenure, greater seniority, or both? Evidence from open-end equity mutual fund managers in Taiwan. Asian Academy of Management Journal of Accounting and Finance, 4(2): 1-20.

Li H, Zhang $X$ and Zhao R. 2011. Investing in talents: Manager characteristics and hedge fund performances. Journal of Financial and Quantitative, 46(1): 59-82.

Lo AW. 2002. The statistics of Sharpe ratios. Financial Analysts Journal, 58(4): 36-52.

McEvoy GM and Cascio WF. 1987. Do good or poor performers leave? A meta-analysis of the relation between performance and turnover. Academy of Management Journal, 30(4): 744-762.

Roll R. 1978. Ambiguity when performance is measured by the securities market line. Journal of Finance, 33(4): 1051-1069.

Sharpe WF. 1966. Mutual fund performance. Journal of Business, 39(1): 119-138. 
Shukla R and Singh S. 1994. Are CFA charterholders better equity fund managers? Financial Analysts Journal, 50(6): 68-74.

Singh S. 2012. Investor irrationality and self-defeating behavior: Insights from behavioral finance. Journal of Global Business Management, 8(1): 116-122.

Treynor J.L. 1965. How to rate management of investment funds. Harvard Business Review, 43(1), 63-75

Treynor J.L. and Mazuy K. 1966. Can mutual funds outguess the market? Harvard Business Review, 44(4): 131-136.

Zhou Z. 2010. Impact of academic experience in economics on risk preferences and rationality: An empirical investigation working paper, Occidental College.

Zuckerman M. 1991. Psychobiology of personality. Cambridge, MA: Cambridge University Press. 


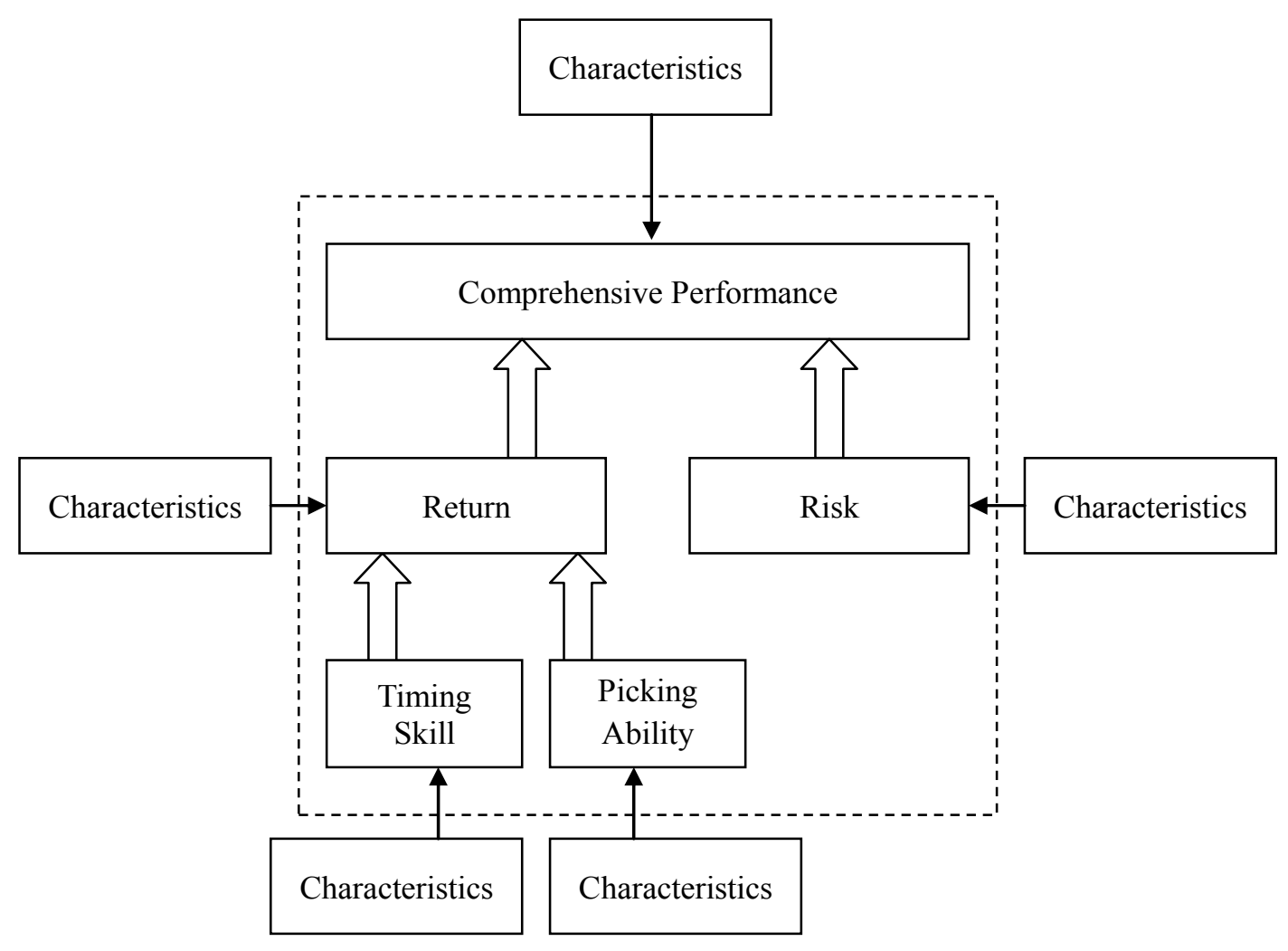

Figure 1 Fund Performance Evaluation Framework 
Table 1: Descriptive statistics

\begin{tabular}{|c|c|c|c|c|c|c|c|}
\hline & Mean & Maximum & Minimum & Std. Dev. & Skewness & Kurtosis & Observations \\
\hline Sharpe ratio & 0.069 & 0.443 & -0.225 & 0.143 & 0.145 & 2.332 & 308 \\
\hline Excess Return & 0.553 & 2.816 & -1.999 & 1.036 & -0.458 & 2.288 & 308 \\
\hline Total Risk & 0.078 & 0.128 & 0.006 & 0.023 & -0.016 & 1.928 & 308 \\
\hline Timing Skill & -0.162 & 5.261 & -10.017 & 1.511 & -1.230 & 10.083 & 308 \\
\hline Picking Ability & 0.006 & 0.038 & -0.026 & 0.009 & 0.410 & 4.290 & 308 \\
\hline GENDER & 0.065 & 1 & 0 & 0.247 & 3.531 & 13.469 & 308 \\
\hline$A G E$ & 36.581 & 48 & 30 & 3.043 & 0.442 & 3.712 & 308 \\
\hline MASTER & 0.705 & 1 & 0 & 0.457 & -0.897 & 1.804 & 308 \\
\hline$P H D$ & 0.114 & 1 & 0 & 0.318 & 2.435 & 6.928 & 308 \\
\hline$M B A$ & 0.123 & 1 & 0 & 0.329 & 2.290 & 6.246 & 308 \\
\hline MAJOR & 0.263 & 1 & 0 & 0.441 & 1.077 & 2.159 & 308 \\
\hline OVERS & 0.075 & 1 & 0 & 0.263 & 3.236 & 11.472 & 308 \\
\hline EXP & 10.500 & 19 & 4 & 3.447 & 0.485 & 2.546 & 308 \\
\hline TURNO & 1.244 & 4 & 1 & 0.544 & 2.280 & 7.717 & 308 \\
\hline$C P A$ & 0.062 & 1 & 0 & 0.241 & 3.644 & 14.276 & 308 \\
\hline$C F A$ & 0.094 & 1 & 0 & 0.293 & 2.779 & 8.725 & 308 \\
\hline
\end{tabular}


Table 2. Panel data results

\begin{tabular}{|c|c|c|c|c|c|}
\hline Variable & $\begin{array}{c}\text { Sharpe } \\
\text { Ratio }\end{array}$ & $\begin{array}{l}\text { Excess } \\
\text { Return }\end{array}$ & $\begin{array}{l}\text { Total } \\
\text { Risk }\end{array}$ & $\begin{array}{c}\text { Timing } \\
\text { Skill }\end{array}$ & $\begin{array}{l}\text { Picking } \\
\text { Ability }\end{array}$ \\
\hline Constant & $\begin{array}{c}0.149^{\star *} \\
(0.0587)\end{array}$ & $\begin{array}{c}1.121^{* *} \\
(0.4723)\end{array}$ & $\begin{array}{c}0.079 * * \\
(0.0079)\end{array}$ & $\begin{array}{c}0.542 \\
(0.6778)\end{array}$ & $\begin{array}{c}0.008 \\
(0.0059)\end{array}$ \\
\hline GENDER & $\begin{array}{c}-0.016 \\
(0.0267)\end{array}$ & $\begin{array}{c}-0.154 \\
(0.1787)\end{array}$ & $\begin{array}{l}-0.005^{\star \star} \\
(0.0021)\end{array}$ & $\begin{array}{c}0.050 \\
(0.2652)\end{array}$ & $\begin{array}{c}-0.001 \\
(0.0022)\end{array}$ \\
\hline$A G E$ & $\begin{array}{l}-0.004^{\star *} \\
(0.0018)\end{array}$ & $\begin{array}{l}-0.027^{\star} \\
(0.0147)\end{array}$ & $\begin{array}{c}0.000 \\
(0.0003)\end{array}$ & $\begin{array}{c}-0.011 \\
(0.0244)\end{array}$ & $\begin{array}{c}0.000 \\
(0.0002)\end{array}$ \\
\hline MASTER & $\begin{array}{c}0.028 \\
(0.0171)\end{array}$ & $\begin{array}{c}0.228^{*} \\
(0.1306)\end{array}$ & $\begin{array}{c}-0.002 \\
(0.0024)\end{array}$ & $\begin{array}{c}-0.282^{*} \\
(0.1645)\end{array}$ & $\begin{array}{c}0.004^{* *} \\
(0.0013)\end{array}$ \\
\hline$P H D$ & $\begin{array}{c}0.027 \\
(0.0222)\end{array}$ & $\begin{array}{c}0.216 \\
(0.1674)\end{array}$ & $\begin{array}{c}-0.002 \\
(0.0031)\end{array}$ & $\begin{array}{c}-0.330 \\
(0.2523)\end{array}$ & $\begin{array}{c}0.006^{* *} \\
(0.0019)\end{array}$ \\
\hline$M B A$ & $\begin{array}{r}0.043^{\star *} \\
(0.0180)\end{array}$ & $\begin{array}{r}0.318^{* *} \\
(0.1568)\end{array}$ & $\begin{array}{c}-0.001 \\
(0.0034)\end{array}$ & $\begin{array}{c}-0.289 \\
(0.2194)\end{array}$ & $\begin{array}{c}0.004^{\star *} \\
(0.0018)\end{array}$ \\
\hline MAJOR & $\begin{array}{c}0.001 \\
(0.0081)\end{array}$ & $\begin{array}{c}-0.033 \\
(0.0644)\end{array}$ & $\begin{array}{l}-0.004^{\star *} \\
(0.0014)\end{array}$ & $\begin{array}{c}-0.088 \\
(0.1011)\end{array}$ & $\begin{array}{c}0.000 \\
(0.0009)\end{array}$ \\
\hline OVERS & $\begin{array}{l}-0.029^{\star \star} \\
(0.0143)\end{array}$ & $\begin{array}{c}-0.180 \\
(0.1160)\end{array}$ & $\begin{array}{c}-0.001 \\
(0.0029)\end{array}$ & $\begin{array}{c}0.0228 \\
(0.2037)\end{array}$ & $\begin{array}{c}-0.001 \\
(0.0019)\end{array}$ \\
\hline EXP & $\begin{array}{c}0.0010 \\
(0.0016)\end{array}$ & $\begin{array}{c}0.007 \\
(0.0133)\end{array}$ & $\begin{array}{c}0.000 \\
(0.0003)\end{array}$ & $\begin{array}{c}0.007 \\
(0.0222)\end{array}$ & $\begin{array}{c}0.000 \\
(0.0002)\end{array}$ \\
\hline TURNO & $\begin{array}{c}0.013 \\
(0.0081)\end{array}$ & $\begin{array}{c}0.083 \\
(0.0613)\end{array}$ & $\begin{array}{c}0.000 \\
(0.0009)\end{array}$ & $\begin{array}{c}-0.052 \\
(0.0996)\end{array}$ & $\begin{array}{c}0.001 \\
(0.0008)\end{array}$ \\
\hline$C P A$ & $\begin{array}{c}0.023 \\
(0.0163)\end{array}$ & $\begin{array}{c}0.188 \\
(0.1336)\end{array}$ & $\begin{array}{c}-0.002 \\
(0.0027)\end{array}$ & $\begin{array}{c}-0.104 \\
(0.1672)\end{array}$ & $\begin{array}{c}0.003^{*} \\
(0.0016)\end{array}$ \\
\hline CFA & $\begin{array}{c}0.033^{* *} \\
(0.0148)\end{array}$ & $\begin{array}{c}0.238^{\star *} \\
(0.1133)\end{array}$ & $\begin{array}{c}0.000 \\
(0.0021)\end{array}$ & $\begin{array}{c}-0.109 \\
(0.1303)\end{array}$ & $\begin{array}{c}0.003^{* *} \\
(0.0014)\end{array}$ \\
\hline Adjusted $R^{2}$ & 0.699 & 0.672 & 0.777 & 0.087 & 0.253 \\
\hline Period $\mathrm{F}$ & $309.781^{\star *}$ & $518.820^{* *}$ & $348.143^{\star *}$ & $47.608^{* *}$ & $18.603^{* *}$ \\
\hline
\end{tabular}

Notes: The superscript * indicates significance at the $10 \%$ level at least and ** suggests significance at the $5 \%$ level at least. Standard errors are presented in parentheses. 
Table 3. Cross-sectional regression results

\begin{tabular}{|c|c|c|c|c|c|}
\hline Variable & $\begin{array}{c}\text { Sharpe } \\
\text { Ratio }\end{array}$ & $\begin{array}{l}\text { Excess } \\
\text { Return }\end{array}$ & $\begin{array}{l}\text { Total } \\
\text { Risk }\end{array}$ & $\begin{array}{c}\text { Timing } \\
\text { Skill }\end{array}$ & $\begin{array}{c}\text { Picking } \\
\text { Ability }\end{array}$ \\
\hline Constant & $\begin{array}{l}0.162^{\star *} \\
(0.0669)\end{array}$ & $\begin{array}{l}1.593^{* *} \\
(0.4847)\end{array}$ & $\begin{array}{l}0.090^{* *} \\
(0.0099)\end{array}$ & $\begin{array}{c}2.262^{*} \\
(1.2203)\end{array}$ & $\begin{array}{c}0.004 \\
(0.0064)\end{array}$ \\
\hline GENDER & $\begin{array}{l}-0.007 \\
(0.0241)\end{array}$ & $\begin{array}{c}-0.065 \\
(0.1732)\end{array}$ & $\begin{array}{l}-0.006^{* *} \\
(0.0024)\end{array}$ & $\begin{array}{l}-0.129 \\
(0.4702)\end{array}$ & $\begin{array}{l}-0.001 \\
(0.0024)\end{array}$ \\
\hline$A G E$ & $\begin{array}{l}-0.004^{*} \\
(0.0022)\end{array}$ & $\begin{array}{l}-0.025^{\star} \\
(0.0154)\end{array}$ & $\begin{array}{c}0.000 \\
(0.0003)\end{array}$ & $\begin{array}{c}-0.063 \\
(0.0429)\end{array}$ & $\begin{array}{c}0.000 \\
(0.0002)\end{array}$ \\
\hline MASTER & $\begin{array}{l}0.042^{\star *} \\
(0.0208)\end{array}$ & $\begin{array}{c}0.201 \\
(0.1344)\end{array}$ & $\begin{array}{c}-0.002 \\
(0.0028)\end{array}$ & $\begin{array}{c}-0.140 \\
(0.2679)\end{array}$ & $\begin{array}{l}0.004^{\star *} \\
(0.0014)\end{array}$ \\
\hline$P H D$ & $\begin{array}{c}0.035 \\
(0.0266)\end{array}$ & $\begin{array}{c}0.208 \\
(0.1722)\end{array}$ & $\begin{array}{c}-0.001 \\
(0.0036)\end{array}$ & $\begin{array}{l}-1.054^{* *} \\
(0.4748)\end{array}$ & $\begin{array}{l}0.005^{\star *} \\
(0.0020)\end{array}$ \\
\hline$M B A$ & $\begin{array}{c}0.046^{*} \\
(0.0236)\end{array}$ & $\begin{array}{l}0.276^{*} \\
(0.152)\end{array}$ & $\begin{array}{c}-0.002 \\
(0.0035)\end{array}$ & $\begin{array}{c}0.081 \\
(0.3996)\end{array}$ & $\begin{array}{l}0.004^{* *} \\
(0.0018)\end{array}$ \\
\hline MAJOR & $\begin{array}{c}-0.002 \\
(0.0100)\end{array}$ & $\begin{array}{c}-0.050 \\
(0.0677)\end{array}$ & $\begin{array}{l}-0.005^{\star *} \\
(0.0018)\end{array}$ & $\begin{array}{c}-0.080 \\
(0.1955)\end{array}$ & $\begin{array}{c}0.000 \\
(0.0009)\end{array}$ \\
\hline OVERS & $\begin{array}{c}-0.013 \\
(0.0186)\end{array}$ & $\begin{array}{l}-0.1771 \\
(0.1177)\end{array}$ & $\begin{array}{c}0.003 \\
(0.0037)\end{array}$ & $\begin{array}{c}-0.284 \\
(0.3051)\end{array}$ & $\begin{array}{c}-0.002 \\
(0.0020)\end{array}$ \\
\hline$E X P$ & $\begin{array}{c}0.001 \\
(0.0021)\end{array}$ & $\begin{array}{c}0.003 \\
(0.0141)\end{array}$ & $\begin{array}{c}0.000 \\
(0.0003)\end{array}$ & $\begin{array}{c}0.041 \\
(0.0436)\end{array}$ & $\begin{array}{c}0.000 \\
(0.0002)\end{array}$ \\
\hline TURNO & $\begin{array}{c}0.009 \\
(0.0088)\end{array}$ & $\begin{array}{c}0.080 \\
(0.0663)\end{array}$ & $\begin{array}{c}0.000 \\
(0.0011)\end{array}$ & $\begin{array}{c}0.048 \\
(0.1882)\end{array}$ & $\begin{array}{c}0.001 \\
(0.0009)\end{array}$ \\
\hline$C P A$ & $\begin{array}{c}0.017 \\
(0.0187)\end{array}$ & $\begin{array}{c}0.208 \\
(0.1410)\end{array}$ & $\begin{array}{l}-0.001 \\
(0.0025)\end{array}$ & $\begin{array}{l}-0.061 \\
(0.3187)\end{array}$ & $\begin{array}{c}0.003 \\
(0.0017)\end{array}$ \\
\hline$C F A$ & $\begin{array}{c}0.039^{* *} \\
(0.0174)\end{array}$ & $\begin{array}{c}0.227^{\star} \\
(0.1258)\end{array}$ & $\begin{array}{l}-0.001 \\
(0.0025)\end{array}$ & $\begin{array}{l}-0.336 \\
(0.2365)\end{array}$ & $\begin{array}{c}0.003^{* *} \\
(0.0015)\end{array}$ \\
\hline Y2009 & $\begin{array}{l}-0.168^{* *} \\
(0.0088)\end{array}$ & $\begin{array}{l}-1.629^{* *} \\
(0.0841)\end{array}$ & $\begin{array}{c}0.001 \\
(0.0024)\end{array}$ & $\begin{array}{l}-0.545^{\star *} \\
(0.1073)\end{array}$ & $\begin{array}{c}0.010^{* *} \\
(0.0013)\end{array}$ \\
\hline Y2010 & $\begin{array}{l}0.095^{\star *} \\
(0.0114)\end{array}$ & $\begin{array}{c}0.235^{\star *} \\
(0.0805)\end{array}$ & $\begin{array}{c}-0.040^{*} \\
(0.0021)\end{array}$ & $\begin{array}{c}-0.267 \\
(0.2063)\end{array}$ & $\begin{array}{c}0.002 \\
(0.0012)\end{array}$ \\
\hline Adjusted $R^{2}$ & 0.668 & 0.693 & 0.735 & 0.043 & 0.275 \\
\hline
\end{tabular}

Notes: The superscript * indicates significance at the $10 \%$ level at least and ** suggests significance at the $5 \%$ level at least. Standard errors are presented in parentheses. 
Table 4. Sharpe ratio decomposition

\begin{tabular}{cc}
\hline Variable & Coefficient \\
\hline Constant & $\begin{array}{c}0.004 \\
(0.0104)\end{array}$ \\
Excess Return & $\begin{array}{c}1.543^{* *} \\
(0.088)\end{array}$ \\
Total Risk & $\begin{array}{c}0.320 \\
(0.2258)\end{array}$ \\
\hline Adjusted $R^{2}$ & 0.909 \\
\hline$\chi^{2}$ value for $\beta_{2}+\beta_{3}=0$ & $32.287^{* *}$ \\
\hline Notes: The superscript $* *$ indicates significance at the $5 \%$ level at \\
least. Standard errors are presented in parentheses. The $\chi^{2}$ value is \\
for a Wald test of $\beta_{2}+\beta_{3}=0$.
\end{tabular}


Table 5. Return decomposition

\begin{tabular}{cc}
\hline Variable & Coefficient \\
\hline C & $\begin{array}{c}0.011 \\
(0.0298)\end{array}$ \\
Timing Skill & $\begin{array}{c}0.110^{* *} \\
(0.0245)\end{array}$ \\
Picking Ability & $\begin{array}{c}0.206^{* *} \\
(0.0169)\end{array}$ \\
\hline Adjusted $R^{2}$ & 0.859 \\
\hline$\chi^{2}$ value for $\beta_{2}-\beta_{3}=0$ & $6.932^{* *}$ \\
\hline
\end{tabular}

Notes: The superscript ** indicates significance at the $5 \%$ level at least.

Standard errors are presented in parentheses. The $\chi^{2}$ value is for a

Wald test of $\beta_{2}-\beta_{3}=0$. 